\title{
Anesthesia and transport of fat snook Centropomus parallelus with the essential oil of Nectandra megapotamica (Spreng.) Mez
}

\author{
Juliana Simoni Moraes Tondolo ${ }^{1,6}$, Lúcio de Paula Amaral², Larissa Novaes Simões ${ }^{3}$, \\ Quelen Iane Garlet ${ }^{1}$, Bianca Schindler ${ }^{2}$, Teodoro Martins Oliveira ${ }^{1}$, Bruno Ferreira da \\ Silva ${ }^{3}$, Levy de Carvalho Gomes ${ }^{3}$, Bernardo Baldisserotto ${ }^{4}$, Carlos Augusto Mallmann ${ }^{5}$, \\ and Berta Maria Heinzmann ${ }^{1,6}$
}

This study analyzed the chemical composition and anesthetic potential of essential oil (EO) of Nectandra megapotamica in fat snook (Centropomus parallelus). For the extraction of EO by hydrodistillation, leaves were separated in young (EO-Y) or old (EO$\mathrm{O}$ ), and the chemical composition of the EOs was determined by CG-MS. The anesthetic potential was assessed by the evaluation of induction and recovery time of anesthesia and stress response from anesthesia and transport. Three experiments were carried out: i) four different concentrations of each $\mathrm{EO}$ were tested to evaluate anesthesia induction and recovery time; ii) two concentrations of EO-O were tested for the evaluation of its effects on stress parameters (glucose, lactate, and $\mathrm{Na}^{+}$and $\mathrm{K}^{+}$plasma levels) caused by anesthesia; and iii) fish were transported in plastic bags, supplied with two concentrations of EO-O for the evaluation of water quality and mortality. All experiments were performed on fish acclimated to 0 and $33 \mathrm{ppt}$ salinity. The main constituents of the $\mathrm{Y}$ and O-EOs were bicyclogermacrene (46.5/34.6\%), $\alpha$-pinene (26.8/26.2\%), $\beta$-pinene (7.9/12.3\%), and germacrene D (9.6/9.1\%). Mild sedation was achieved at $30 \mu \mathrm{L} \mathrm{L}^{-1}(1.3-3.2 \mathrm{~min})$ and deep anesthesia at $150 \mu \mathrm{L} \mathrm{L}^{-1}$ (5.6-8.0 min) with both EOs. The recovery time ranged from 1-10 min. The EO-O was not able to avoid the stress of anesthesia evidenced by elevated glucose and lactate plasma levels observed in all groups. Plasma levels of $\mathrm{Na}^{+}$and $\mathrm{K}^{+}$were not significantly affected by treatments. During transport, the use of EO-O did not prevent deterioration in water quality and the post-transport mortality. In conclusion, the EO of N. megapotamica has anesthetic activity in fat snook, but it was not able to prevent the stress of anesthesia and transport.

Este estudo analisou a composição química e o potencial anestésico do óleo essencial (OE) de Nectandra megapotamica em robalos-peva (Centropomus parallelus). Para a extração do OE por hidrodestilação, as folhas foram separadas em jovens (OE-J) ou velhas $(\mathrm{OE}-\mathrm{V})$ e a composição química foi determinada por CG-EM. O potencial anestésico foi acessado através da avaliação do tempo de indução e recuperação da anestesia e resposta ao estresse do procedimento anestésico e transporte. Foram realizados três experimentos: em primeiro lugar, quatro concentrações diferentes de cada OE foram testadas para avaliar o tempo de indução à anestesia e de recuperação; em segundo lugar, duas concentrações do OE-V foram testadas para avaliar os efeitos sobre os parâmetros de estresse (níveis plasmáticos de glicose, lactato, $\mathrm{Na}^{+}$e $\mathrm{K}^{+}$) causados pelo procedimento anestésico; em terceiro lugar, os peixes foram transportados em sacos plásticos com duas concentrações do OE-V para avaliação da qualidade da água e mortalidade. Todos os experimentos foram realizados em peixes aclimatados à salinidade zero e 33 . Os constituintes majoritários do OE-J e OE-V foram: biciclogermacreno (46,5/34,6\%), $\alpha$-pineno $(26,8 / 26,2 \%)$, $\beta$-pineno $(7,9 / 12,3 \%)$ e germacreno D (9,6/9,1\%). Sedação leve foi alcançada com $30 \mu \mathrm{L} \mathrm{L}^{-1}(1,3-3,2 \mathrm{~min})$ e anestesia profunda a partir de $150 \mu \mathrm{L} \mathrm{L}^{-1}(5,6-8,0 \mathrm{~min}) \mathrm{com}$ ambos OEs. O tempo de recuperação variou entre 1-10 min.O OE-V não foi capaz de evitar o estresse do procedimento anestésico,

\footnotetext{
${ }^{1}$ Universidade Federal de Santa Maria, Departamento de Farmácia Industrial. Av. Roraima n 1000, Prédio 26, Campus Camobi, $97105-900$ Santa Maria, RS, Brazil. queling@hotmail.com (QIG), teodoro.oliveira@gmail.com (TMO)

${ }^{2}$ Universidade Federal de Santa Maria, Programa de Pós-Graduação em Engenharia Florestal, Centro de Ciências Rurais II. Av. Roraima n ${ }^{\circ}$ 1000, Prédio 44, Campus Camobi, 97105-900 Santa Maria, RS, Brazil. lpamaralengflorestal@gmail.com (LPA), biaschindler@gmail.com(BS) ${ }^{3}$ Universidade de Vila Velha, Laboratório de Ictiologia Aplicada. Rua Comissário José Dantas de Melo n 21, Boa Vista, 29102-770 Vila Velha, ES, Brazil.larissanovaess@hotmail.com(LNS), bferreiradasilva@gmail.com(BFS), levycg@yahoo.com.br(LCG)

${ }^{4}$ Universidade Federal de Santa Maria, Departamento de Fisiologia e Farmacologia. Av. Roraima n 1000, Prédio 21, Campus Camobi, 97105-900 Santa Maria, RS, Brazil. bbaldisserotto@hotmail.com (BB)

${ }^{5}$ Universidade Federal de Santa Maria, Departamento de Medicina Veterinária Preventiva, Centro de Ciências Rurais. Av. Roraima n ${ }^{\circ} 1000$, Prédio 44, Campus Camobi, 97105-900 Santa Maria, RS, Brazil. mallmann@lamic.ufsm.br(CAM)

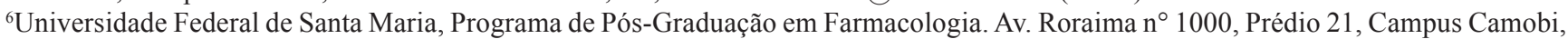
97105-900 Santa Maria, RS, Brazil. jutondolo@yahoo.com.br (JSMT), berta.heinzmann@gmail.com (BMH)
} 
evidenciado pelos elevados níveis plasmáticos de glicose e lactato observados em todos os grupos. Os níveis plasmáticos de $\mathrm{Na}^{+}$e K ${ }^{+}$não foram significativamente afetados pelos tratamentos. Durante o transporte, o OE-V não impediu a deterioração da qualidade da água e a mortalidade pós-transporte. Concluindo, o OE de Nectandra megapotamica apresenta atividade anestésica em robalos-peva, mas não foi capaz de evitar o estresse do procedimento anestésico e transporte.

Key words: Fish, Ionoregulation, Sedation, Stress, Terpenoids.

\section{Introduction}

Anesthetics are used in modern aquaculture management to minimize stress or physical damage caused by handling, transport, and more invasive procedures that may cause poor performance, immunosuppression, and increased mortality in fish (Gray et al., 2011). A variety of anesthetics such as tricaine methanesulphonate (MS-222), 2-phenoxyethanol, quinaldine, benzocaine, and metomidate have been used for this purpose (Ross \& Ross, 2008). However, the use of some anesthetics has been limited or rejected due to undesirable side effects for fish and humans (Palic et al., 2006). Alternatively, several studies using plant derivative compounds, such as essential oils (EOs) from Eugenia, Mentha, and Lippia species, have demonstrated that these natural products are effective for fish sedation and may have benefits over traditional methods, including lower cost and higher safety (Cunha et al., 2010a; Gonçalves et al., 2008; Palic et al., 2006).

The genus Nectandra Rol. Ex Rottb (Lauraceae) includes more than 100 recognized species of canopy trees mainly distributed from Amazon to Southern Brazil, Argentina, Paraguay, and Uruguay (Alves \& Sartori, 2009). Nectandra megapotamica (Spreng.) Mez is popularly known as "canela-preta" and its barks have been used in folk medicine as anti-rheumatic and analgesic (Santos Filho \& Gilbert, 1975) and its leaves have been used as sedative (Alves et al., 2008). Previous pharmacological investigation using mice and rats have showed analgesic and anti-inflammatory activities for the bark hydroalcoholic extract of this species (da Silva et al., 2004). Additionally, studies have showed that the ethanolic extract from the trunk bark presents antioxidant and antimicrobial activities (Garcez et al., 2009), while for the leaf essential oil, literature describes anti-inflammatory and antitumor activities (Apel et al., 2006).

Snooks (Centropomus spp.) have been recognized as fish with great potential for aquaculture due to their fast growth, highly efficient food conversion ratios and energy utilization (Alvarez-Lajonchere \& Tsuzuki, 2008). In the production process, the transport of juveniles is one of the most important steps in the management and marketing of fish. This practice inevitably involves stress and may cause a large-scale mortality. Several studies have shown the positive effect of anesthetics during transport of many fish species (Inoue et al., 2005; Iversen et al., 2009; Pramod et al., 2010).

The objective of the present study was to determine the anesthetic potential of the EO of $N$. megapotamica evaluating the induction and recovery times from anesthesia as well as its effect on biochemical and osmoregulatory parameters related to stress of anesthesia and transport in fat snook,
Centropomus parallelus. Additionally, the chemical composition of the EO was analyzed in order to determine the possible substances responsible for the detected activity.

\section{Material and Methods}

Experimental fish. Fat snook juveniles were purchased from Pandini Fish Culture (São Mateus, ES, Brazil) and transported to the Laboratory of Fish Culture at Universidade Federal do Espírito Santo (UFES - Aracruz), where they were gradually acclimated to freshwater (FW) (reducing 10 ppt each day) or maintained in 33 ppt (seawater (SW) salinity in the tanks where fish were raised) for 10 days. They were kept in continuously aerated tanks of 500 $\mathrm{L}$ (small fish) and $1000 \mathrm{~L}$ (large fish), fed with commercial pellets NRD $1.2\left(\right.$ Inve $\left.^{\circledR}\right)$ three times a day and fasted $24 \mathrm{~h}$ before the experiments. Data on water quality parameters $[\mathrm{FW} / \mathrm{SW}]$ were: conductivity (mS), 0.183 - 5.3 / 49.6 - 55.2; salinity (ppt), 0 / 33.1 35.2 ; temperature $\left({ }^{\circ} \mathrm{C}\right), 23.1-25.1 / 24.2$ - 27.0; dissolved oxygen $\left(\mathrm{mg} \mathrm{L}^{-1}\right), 7.62$ - 7.87/ 7.15 - 7.62. Data were measured using an YSI 85 multiparameter instrument.

Plant material. The plant Nectandra megapotamica was collected from native forests of Santa Maria, State of Rio Grande do Sul, Southern Brazil. The aerial parts of the plant were collected in November 2010 and identified by Prof. Dr. Solon Jonas Longhi from the Department of Forestry Engineering, Universidade Federal de Santa Maria (UFSM) . A voucher specimen (SMDB N. 13107) was deposited in the herbarium of the Departamento de Biologia, UFSM. The leaves were classified into young $(\mathrm{Y})$ and old $(\mathrm{O})$ samples considering the arrangement of leaves on the branches, with nodes and internodes at different cycles of tree growth as control (Penfold $\&$ Willis, 1961). Size, texture, color and particle deposition on the upper surface of the sheet were also considered.

Essential oil extraction. The young and old leaves were submitted separately to hydrodistillation using a Clevenger type apparatus for $3 \mathrm{~h}$. In this method, the distillate is collected in a graduated glass tube and the aqueous phase is automatically reused into the distillation flask (Council of Europe, 2007). The EO from young leaves (EO-Y) and old leaves (EO-O) was stored at $-4^{\circ} \mathrm{C}$ in amber glass bottles.

Volatile oil analysis and identification of constituents. EO samples were analyzed by gas chromatography-mass spectrometry (GC-MS), using an Agilent 6890N chromatograph coupled with an Agilent 5973 mass selective detector operating at $70 \mathrm{eV}$. The analyses were carried out using a HP-5MS capillary 
column $(30 \mathrm{~m} \times 0.25 \mathrm{~mm} \times 0.25 \mu \mathrm{m})$, injecting $1.0 \mu \mathrm{L}$ of a solution at $1.0 \mu \mathrm{L} \mathrm{mL}^{-1}$ of EO in hexane in split inlet mode (1:100). The carrier gas $(\mathrm{He})$ flow rate was $1.3 \mathrm{~mL} \mathrm{~min}^{-1}$, injector and detector temperatures were set at 250 and $320^{\circ} \mathrm{C}$, respectively. The oven temperature was programmed from $40-320^{\circ} \mathrm{C}$ at $4^{\circ} \mathrm{C} \mathrm{min}^{-1}$. The identification of the individual $\mathrm{EO}$ components was accomplished by comparison of the Kovats retention index with literature data and by matching mass spectral data with those available in the system (Adams, 2001; NIST, 2002). For quantitative analysis, the percentage composition of the EO samples was computed by integrating the peak area of the chromatograms.

Anesthesia induction and recovery. Snook fingerlings $(0.49 \pm 0.03$ $\mathrm{g}$ and $3.65 \pm 0.08 \mathrm{~cm}, n=8$ per treatment) were transferred to glass aquaria contained $100 \mathrm{~mL}$ of FW or SW and the EOs (Y or O) of Nectandra megapotamica at concentrations of 30, 150, 300 and $450 \mu \mathrm{L} \mathrm{L}^{-1}$ (equivalent to 24, 120, 240 and $360 \mathrm{mg} \mathrm{L}^{-1}$, respectively because the density of this $\mathrm{EO}$ was approximately 0.80). EO samples were first diluted in ethanol (1:10). Control experiments were performed using aquaria that contained only ethanol at concentrations equivalent to the dilutions used for 300 and $450 \mu \mathrm{L} \mathrm{L}^{-1} \mathrm{EO}\left(2700\right.$ and $\left.4050 \mu \mathrm{L} \mathrm{L}^{-1}\right)$. To evaluate the time required for anesthesia induction, fingerlings were evaluated individually, and each fingerling was used only once. The stages of anesthesia were evaluated according to the method of Stoskopf (1993) where the following stages (S) can be observed: $\mathrm{S} 1$, slight loss of reactivity to visual and tactile stimuli; S2, partial loss of equilibrium; S3, total loss of equilibrium; S4, reduced opercular movement; S5, minimal opercular movement; REC, recovery of equilibrium and swimming activity. The observation time was $10 \mathrm{~min}$ and at the end of this period juveniles were transferred to anesthetic-free aquaria to measure the anesthesia recovery time.

Biochemical and osmoregulatory parameters. Juveniles (37.2 $\pm 4.03 \mathrm{~g}$ and $28.7 \pm 3.77 \mathrm{~g}$, for FW and SW adapted fish, respectively; $n=6$ for group) were anesthetized with 30 and $300 \mu \mathrm{L} \mathrm{L}^{-1}$ EO-O of Nectandra megapotamica first diluted in ethanol (1:10) in aquaria containing $1 \mathrm{~L}$ of FW or SW. These two concentrations were chosen after the induction and recovery trials. Fish taken directly from the main tank (FW or SW) were used as baseline control values (BC) and fish kept in anesthetic-free aquaria for $10 \mathrm{~min}$ (simulating anesthesia procedure) were considered aquarium control (AC). After anesthesia, blood was collected from the caudal vein and glucose levels were determined with the digital Accu-Chek Active (Roche ${ }^{\mathrm{TM}}$ ). The remaining blood was centrifuged at 3000 rpm for $10 \mathrm{~min}$ and plasma was then frozen for later analysis. Plasma $\mathrm{Na}^{+}$and $\mathrm{K}^{+}$levels were determined with a flame photometer Analyser 910 (Analyser, São Paulo, Brazil) and plasma lactate levels by means of biochemical kit (Bioclin, K084) using a semi-automatic biochemical analyzer (Model BIO-200F; Bioplus, Brazil). Immediately after blood collection, fish were euthanized by cervical section to remove the gills and muscle for tissue hydration determination. After weighing, the tissues (wet weight) were dried for $24 \mathrm{~h}$ at $60^{\circ} \mathrm{C}$ and then weighed again (dry weight). The loss in weight (water) was expressed as a percentage of the initial wet weight of the sample.

Transportation experiment. Fish were removed from the acclimation tanks and placed in $4 \mathrm{~L}$ polyethylene bags with $1 \mathrm{~L}$

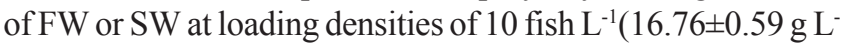
$\left.{ }^{1}\right)$ for FW and 25 fish $\mathrm{L}^{-1}\left(11.16 \pm 0.24 \mathrm{~g} \mathrm{~L}^{-1}\right)$ for SW. The EO-O of Nectandra megapotamica, firstly diluted in ethanol (1:10), was added to plastic bags at 15 or $30 \mu \mathrm{L} \mathrm{L}^{-1}$. Control groups used only water or ethanol at the same concentration used for dilution of $30 \mu \mathrm{L} \mathrm{L}^{-1}$ of EO. The bags were inflated with pure oxygen and then sealed. The experiment was performed in triplicate. The transport was carried out on paved and unpaved roads for $10 \mathrm{~h}$ (usual time of transport of fingerlings of this species in Brazil). Water quality parameters (temperature, $\mathrm{pH}$, conductivity, oxygen, and ammonia) were analyzed before and after transport and mortality was observed at times zero (arrival), 12, 60 and 84 $\mathrm{h}$ after transport. Total ammonia was determined by indophenol blue method (American Public Health Association, 1998) and other parameters as previously described. Ammonia excretion was calculated according to Gonzales et al. (1998).

Statistical analyses. All data are represented as mean $\pm \mathrm{SEM}$ and were subjected to Levene's test to check homogeneity of variances. Data from the time of anesthesia induction and recovery were subjected to logarithmic transformation to obtain homogeneity between groups and two-way ANOVA followed by Tukey test were performed to test for difference between groups. Data expressed in percentages (mortality) were subjected to arcsine transformation and analyzed by two-way ANOVA followed by Tukey test. Biochemical and osmoregulatory parameters were analyzed by one-way ANOVA. The relationship between anesthetic concentration and time to reach each anesthetic stage or recovery were assessed using Sigma Plot 11.0 software. Significant difference was established at $\mathrm{P}<0.05$.

\section{Results}

Volatile oil analysis and identification of constituents. A total of 23 and 21 compounds were identified in the EO-Y and EOO, accounting for $99.86-99.81 \%$ of their total composition, respectively. These EOs of Nectandra megapotamica were composed largely of monoterpene and sesquiterpene hydrocarbons. The main constituents of the EO-Y and EO-O were bicyclogermacrene (46.5/34.6\%), $\alpha$-pinene $(26.8 / 26.2 \%)$, $\beta$-pinene (7.9/12.3\%), and germacrene D (9.6/9.1\%) (Table 1).

Anesthesia induction and recovery. As expected, the increasing concentration of EOs proportionally decreased the time required for sedation and anesthesia induction in most stages, but increased recovery time (Table 2). The greater induction time for $150 \mu \mathrm{L}$ of EO-Y in comparison with $30 \mu \mathrm{L}$ cannot be explained by current knowledge. Further studies at molecular level should be performed to clarify this fact. All fish recovered from anesthesia within $30 \mathrm{~min}$ and no mortality was registered in the course of the experiment. For anesthesia induction, $30 \mu \mathrm{L} \mathrm{L}^{-1} \mathrm{EO}-\mathrm{O}$ was able to 
induce stages 1-4, but stages 3 and 4 in FW and stage 4 in SW were reached by only $25,37.5$, and $25 \%$ of fish, respectively. Fat snooks acclimated to $\mathrm{SW}$ and exposed to the same concentration of EO-Y did not reach stage 3 and fish recovered before the end of exposure to this EO. From the $150 \mu \mathrm{L} \mathrm{L}^{-1} \mathrm{EO}-\mathrm{Y}$ and EO-O all fish reached stage 4 (reduced opercular movement) and minimal opercular movement (stage 5) was reached only by fish exposed to $450 \mu \mathrm{L} \mathrm{L}^{-1} \mathrm{EO}-\mathrm{Y}$, in both type of water (Table 2).

There was no significant difference in the time to reach the different stages of anesthesia in $\mathrm{FW}$-adapted fat snook exposed to 30 and $300 \mu \mathrm{L} \mathrm{L}^{-1} \mathrm{EO}-\mathrm{Y}$ and EO-O. The induction times to stage 3 at $150 \mu \mathrm{L} \mathrm{L}^{-1} \mathrm{EO}-\mathrm{O}$ and stage 1 at $450 \mu \mathrm{L} \mathrm{L}^{-1} \mathrm{EO}-\mathrm{O}$ were significantly lower than those using EO-Y at the same concentrations in FW. Tests in SW showed no significant difference between induction time for the different stages with EO-Y or EO-O at $30 \mu \mathrm{L} \mathrm{L}^{-1}$, while time to reach stage 1 at 150,300 and $450 \mu \mathrm{L} \mathrm{L}^{-1} \mathrm{EO}-\mathrm{O}$ and time to reach stage 2 at $300 \mu \mathrm{L} \mathrm{L}^{-1} \mathrm{EO}-$ $\mathrm{O}$ was significantly higher than using $\mathrm{EO}-\mathrm{Y}$. The induction time to stage 3 was significantly lower at $450 \mu \mathrm{L} \mathrm{L}^{-1} \mathrm{EO}-\mathrm{O}$ than with $\mathrm{EO}-\mathrm{Y}$ in SW. Recovery time was significantly higher at 150 and $450 \mu \mathrm{L} \mathrm{L}^{-1} \mathrm{EO}-\mathrm{O}$ in SW and at $450 \mu \mathrm{L} \mathrm{L}^{-1} \mathrm{EO}-\mathrm{O}$ in $\mathrm{FW}$ when compared to the correspondent data of EO-Y (Table 2).

Time to reach the different anesthesia stages at 30 and 150 $\mu \mathrm{L} \mathrm{L}^{-1} \mathrm{EO}-\mathrm{Y}$ was not affected by FW or SW adaptation. In SW, induction times to reach stage 3 were significantly higher than

Table 1. Constituents of the young (EO-Y) and old leaf essential oil (EO-O) of Nectandra megapotamica. $\mathrm{RI}_{\text {lit }}=$ retention index from literature; $\mathrm{RI}_{\text {exp }}=$ experimental retention index; NI = not identified; $a=$ Adams (2001); $b=$ databank NIST (2002).

\begin{tabular}{|c|c|c|c|c|c|}
\hline \multirow{2}{*}{ Compound } & \multirow[b]{2}{*}{$\mathrm{RI}_{\text {lit }}$} & \multicolumn{2}{|c|}{ EO-Y } & \multicolumn{2}{|c|}{ EO-O } \\
\hline & & $\%$ & $\mathrm{RI}_{\exp }$ & $\%$ & $\mathrm{RI}_{\exp }$ \\
\hline$\alpha$-pinene & $931 \mathrm{~b}$ & 26.82 & 933 & 26.19 & 930 \\
\hline camphene & $943 \mathrm{~b}$ & 0.23 & 944 & 0.67 & 943 \\
\hline$\beta$-pinene & $973 \mathrm{~b}$ & 7.95 & 973 & 12.30 & 972 \\
\hline$\beta$-myrcene & $991 \mathrm{a}$ & 1.38 & 991 & 2.39 & 990 \\
\hline limonene & $1026 \mathrm{~b}$ & 2.31 & 1026 & 4.61 & 1026 \\
\hline 1,8-cineole & $1029 \mathrm{~b}$ & 0.27 & 1028 & 0.56 & 1028 \\
\hline$\beta$-Z-ocimene & $1037 \mathrm{a}$ & 0.06 & 1037 & - & - \\
\hline$\beta$-E-ocimene & $1050 \mathrm{a}$ & 0.43 & 1048 & 0.74 & 1049 \\
\hline terpinolene & $1086 \mathrm{~b}$ & 0.07 & 1086 & - & - \\
\hline linalool & $1097 \mathrm{a}$ & 0.28 & 1099 & 0.71 & 1100 \\
\hline$\delta$-elemene & $1338 \mathrm{a}$ & 0.22 & 1337 & 1.13 & 1338 \\
\hline$\alpha$-copaene & $1377 \mathrm{a}$ & 0.50 & 1376 & 0.46 & 1377 \\
\hline NI & - & - & - & 0.18 & 1386 \\
\hline$\beta$-cubebene & $1390 \mathrm{~b}$ & 0.11 & 1390 & 0.15 & 1391 \\
\hline$\beta$-elemene & $1393 \mathrm{~b}$ & 0.11 & 1392 & 0.52 & 1393 \\
\hline$\beta$-caryophyllene & $1420 \mathrm{~b}$ & 1.48 & 1420 & 2.39 & 1421 \\
\hline$\alpha$-caryophyllene & $1455 \mathrm{a}$ & 0.37 & 1454 & 0.52 & 1455 \\
\hline germacrene D & $1485 \mathrm{a}$ & 9.61 & 1484 & 9.20 & 1483 \\
\hline$\alpha$-selinene & $1490 \mathrm{~b}$ & 0.25 & 1487 & 0.34 & 1488 \\
\hline bicyclogermacrene & $1500 \mathrm{a}$ & 46.47 & 1501 & 34.56 & 1499 \\
\hline$\delta$-cadinene & $1523 \mathrm{~b}$ & 0.63 & 1524 & 0.70 & 1525 \\
\hline$E$-nerolidol & $1563 \mathrm{a}$ & 0.14 & 1564 & - & - \\
\hline spathulenol & $1578 \mathrm{a}$ & - & - & 1.06 & 1580 \\
\hline globulol & $1585 \mathrm{a}$ & 0.17 & 1585 & 0.62 & 1587 \\
\hline NI & - & 0.14 & 1593 & - & - \\
\hline Total identified & & 99.85 & & 99.82 & \\
\hline Yield & & 0.30 & & 0.20 & \\
\hline
\end{tabular}

in FW at 300 and $450 \mu \mathrm{L} \mathrm{L}^{-1} \mathrm{EO}-\mathrm{Y}$, but time to reach stage 1 at $450 \mu \mathrm{L} \mathrm{L}^{-1} \mathrm{EO}-\mathrm{Y}$ had a significantly lower induction time. Fat snooks exposed to $150 \mu \mathrm{L} \mathrm{L}^{-1} \mathrm{EO}-\mathrm{O}$ had significantly higher induction times to stages 1,2 and 3 in SW than in FW. Recovery time was significantly higher at 300 and $450 \mu \mathrm{L} \mathrm{L}^{-1} \mathrm{EO}-\mathrm{Y}$ and 150,300 , and $450 \mu \mathrm{LL}^{-1} \mathrm{EO}-\mathrm{O}$ in SW than in FW. All fish (FW or SW adapted) exposed to $2700 \mu \mathrm{L} \mathrm{L}^{-1}$ ethanol alone reached the stage 1 within $30 \mathrm{~s}$, but $87.5 \%$ showed full recovery even in ethanol after $2 \mathrm{~min}$. Fat snooks exposed to $4050 \mu \mathrm{L} \mathrm{L}^{-1}$ ethanol reached stage 1 within $10 \mathrm{~s}$. Half of the fish reached the stage 3 in $20 \mathrm{~s}$, but after 2 min only $25 \%$ of the total remained in this stage up to the end of the observation (10 min). Recovery was immediate in aquaria containing only water.

Biochemical and osmoregulatory parameters. Fish subjected to simulation of anesthesia (AC) and exposed to 30 and $300 \mu \mathrm{L} \mathrm{L}^{-}$ ${ }^{1} \mathrm{EO}-\mathrm{O}$ in SW showed significantly higher plasma glucose and lactate levels compared to basal control (BC), but groups did not show significant difference between each other. Both parameters were significantly higher in $\mathrm{FW}$-adapted fat snooks anesthetized with $300 \mu \mathrm{L} \mathrm{L}^{-1} \mathrm{EO}-\mathrm{O}$ when compared to $\mathrm{BC}$ group. Plasma glucose levels were significantly higher in SW fish subjected to $\mathrm{AC}$ and exposed to 30 and $300 \mu \mathrm{L} \mathrm{L}^{-1} \mathrm{EO}-\mathrm{O}$ than in FW fish subjected to the same treatments. SW-adapted fat snooks subjected to AC also presented significantly higher lactate levels than FW fish submitted to the same treatment (Table 3 ).

The different treatments (AC, 30 and $300 \mu \mathrm{L} \mathrm{L}^{-1}$ ) did not change significantly the plasma $\mathrm{Na}^{+}$and $\mathrm{K}^{+}$levels in fish kept at either salinities. Plasma $\mathrm{Na}^{+}$levels of fish from $\mathrm{BC}, \mathrm{AC}$ and 30 $\mu \mathrm{L} \mathrm{L}^{-1}$ groups maintained in SW were significantly higher than those of the same groups kept in FW. No significant differences were observed for plasma $\mathrm{K}^{+}$levels between fat snooks from either salinities (Table 3). Overall muscle and gill water content was ca. $80 \%$ and $68-74 \%$, respectively, for all groups and was not affected significantly by treatments or salinity (Table 4 ).

Transportation experiment. After $10 \mathrm{~h}$ transportation, in FWacclimated groups there was no death on the arrival. Posttransport mortality was low up to the end of $84 \mathrm{~h}$ and showed no significant difference between groups (Fig 1A). In SWacclimated fat snooks mortality ranged from $2.6-12 \%$ and increased up to $12 \mathrm{~h}$, differing statistically from arrival. Posttransport mortality was significantly higher in fish transported with $30 \mu \mathrm{LL}^{-1} \mathrm{EO}-\mathrm{O}$ (Fig. 1B). Water quality parameters at the end of transportation and ammonia excretion did not show any statistical differences between treatments for either water types. The range in water temperature, conductivity and $\mathrm{pH}$ at the end of transportation $\left(24.97-25.23^{\circ} \mathrm{C} / 27.70-28.66^{\circ} \mathrm{C}, 0.11-0.12\right.$ / 54.30-55.66 mS, 6.47-6.67 / 6.66-6.95, respectively for FW / SW) also did not show any statistical differences compared with water before transport $\left(24 / 29^{\circ} \mathrm{C}, 0.134 / 52.7 \mathrm{mS}, 7.04 / 7.64\right.$, respectivelyfor FW / SW). The dissolved oxygen level before adding pure oxygen for transport in plastics bags was 7.75/ $7.77 \mathrm{mg} \mathrm{L}^{-1}$ for $\mathrm{FW} / \mathrm{SW}$, respectively, and at the end of the transport was supersaturated (higher than 200\%) for all groups in both salinities. Total ammonia levels increased significantly 
Table 2. Time (in seconds) required for induction and recovery from anesthesia using the essential oil of Nectandra megapotamica in fat snook. Stages are according to Stoskopf (1993): S1, slight loss of reactivity to visual and tactile stimuli; S2, partial loss of equilibrium; S3, total loss of equilibrium; S4, reduced opercular movement; S5, minimal opercular movement; REC, recovery of equilibrium and swimming actively; Maximum observation time was $10 \mathrm{~min} . \mathrm{N}=8$ for each concentration tested. $\S$, number of observations lower than 3 (data not used for statistical comparison); *, significantly different from EO-Y in the same salinity; \#, significantly different from freshwater with the same essential oil; -, stage not reached by any of the animals.

\begin{tabular}{|c|c|c|c|c|c|c|c|c|}
\hline \multicolumn{5}{|c|}{ EO-Y $\left(\mu L_{L}^{-1}\right)$} & \multicolumn{4}{|c|}{ EO-O $\left(\mu \mathrm{L} \mathrm{L}^{-1}\right)$} \\
\hline \multicolumn{9}{|c|}{ Freshwater } \\
\hline & 30 & 150 & 300 & 450 & 30 & 150 & 300 & 450 \\
\hline S1 & $22.5 \pm 5.5$ & $47.6 \pm 18.1$ & $29.5 \pm 5.3$ & $26.8 \pm 4.4$ & $28.8 \pm 3.5$ & $16.0 \pm 1.4$ & $21.5 \pm 2.1$ & $16.8 \pm 0.9 *$ \\
\hline $\mathrm{S} 2$ & $76.2 \pm 24.2$ & $75.1 \pm 16.4$ & $42.7 \pm 3.0$ & $35.2 \pm 6.2$ & $192.0 \pm 49.0$ & $42.3 \pm 5.5$ & $36.1 \pm 3.4$ & $29.0 \pm 1.1$ \\
\hline S3 & $213.7 \pm 54.2$ & $295.5 \pm 55.0$ & $158.8 \pm 25.6$ & $159.3 \pm 45.8$ & $370.5 \pm 36.4 \S$ & $123.6 \pm 19.2 *$ & $214.0 \pm 33.8$ & $260.1 \pm 34.2$ \\
\hline S4 & $294.7 \pm 43.3$ & $449.2 \pm 40.3$ & $371.1 \pm 54.6$ & $371.1 \pm 54.6$ & $420.3 \pm 20.6 \S$ & $337.2 \pm 47.0$ & $393.6 \pm 35.0$ & $368.7 \pm 33.4$ \\
\hline S5 & - & - & - & $322.0 \pm 116.3$ & - & - & - & - \\
\hline REC & $78.0 \pm 37.2$ & $334.5 \pm 40.8$ & $314.1 \pm 74.6$ & $405.1 \pm 64.7$ & $35.8 \pm 14.8$ & $341.5 \pm 78.3$ & $478.1 \pm 24.3$ & $910.7 \pm 81.8^{*}$ \\
\hline \multicolumn{9}{|c|}{ Seawater } \\
\hline S1 & $21.0 \pm 3.2$ & $16.8 \pm 2.1$ & $12.5 \pm 1.0$ & $11.2 \pm 1.2 \#$ & $20.1 \pm 1.8$ & $26.2 \pm 3.2 * \#$ & $17.7 \pm 1.0 *$ & $16.3 \pm 1.0 *$ \\
\hline $\mathrm{S} 2$ & $122.0 \pm 39.0$ & $79.7 \pm 8.7$ & $35.6 \pm 2.8$ & $26.5 \pm 4.0$ & $123.7 \pm 11.4$ & $79.1 \pm 5.4 \#$ & $49.1 \pm 5.0^{*}$ & $32.3 \pm 3.1$ \\
\hline S3 & - & $437.7 \pm 34.5$ & $386.5 \pm 46.5 \#$ & $365.0 \pm 24.8 \#$ & $349.1 \pm 47.2$ & $347.4 \pm 38.9 \#$ & $260.1 \pm 16.5$ & $283.2 \pm 17.1 *$ \\
\hline S4 & $429.4 \pm 36.4$ & $481.3 \pm 16.1$ & $469.3 \pm 41.5$ & $436.5 \pm 17.7$ & $497.0 \pm 48.0 \S$ & $469.4 \pm 47.3$ & $413.7 \pm 26.8$ & $406.8 \pm 20.2$ \\
\hline S5 & - & - & - & $514.0 \pm 17.3$ & - & - & - & - \\
\hline REC & - & $350.3 \pm 44.7$ & $508.6 \pm 115.5 \#$ & $721.2 \pm 64.7 \#$ & $72.3 \pm 9.3$ & $657.3 \pm 69.3^{* \#}$ & $849.0 \pm 54.2 \#$ & $1270.3 \pm 58.1 * \#$ \\
\hline
\end{tabular}

for all groups at the end transport (range of groups: 2.18-3.28/ 2.85-3.14 $\left.\mathrm{mg} \mathrm{L}^{-1} \mathrm{FW} / \mathrm{SW}\right)$ compared to before transport $(0.03$ / $0.04 \mathrm{mg} \mathrm{L}^{-1} \mathrm{FW} / \mathrm{SW}$ ). The ammonia excretion levels did not show significant difference between groups or salinities (range of groups: 13.92-19.48 / 26.30-27.81 $\mathrm{mg} \mathrm{kg}^{-1} \mathrm{~h}^{-1} \mathrm{FW} / \mathrm{SW}$ )

\section{Discussion}

Analysis of the major constituents of the EO-Y and EO-O of Nectandra megapotamica indicated almost the same qualitative composition. Both EOs presented bicyclogermacrene, $\alpha$ - and $\beta$-pinene and germacrene $D$ as major

Table 3. Plasma glucose, lactate, $\mathrm{Na}^{+}$and $\mathrm{K}^{+}$levels in fat snook Centropomus parallelus acclimated to fresh- or seawater and exposed for $10 \mathrm{~min}$ to the essential oil from old leaves of Nectandra megapotamica (30 and $300 \mu \mathrm{L} \mathrm{L}^{-1}$ ). BC: basal control; AC: aquarium control. Data presented as means \pm $\operatorname{SEM}(n=6)$. Different lower case letters indicate significant difference between groups in the same salinity, while capital letters indicate significant difference between salinities in the same group.

\begin{tabular}{lcccc}
\hline \multicolumn{3}{c}{ Freshwater } & \multicolumn{2}{c}{ Seawater } \\
\hline Groups & $\begin{array}{c}\text { Glucose } \\
\left(\mathrm{mg} \mathrm{dL}^{-1}\right)\end{array}$ & $\begin{array}{c}\text { Lactate } \\
\left(\mathrm{mg} \mathrm{dL}^{-1}\right)\end{array}$ & $\begin{array}{c}\text { Glucose } \\
\left(\mathrm{mg} \mathrm{dL}^{-1}\right)\end{array}$ & $\begin{array}{c}\text { Lactate } \\
\left(\mathrm{mg} \mathrm{dL}^{-1}\right)\end{array}$ \\
\cline { 2 - 5 } $\mathrm{BC}$ & $45.16 \pm 9.25^{\mathrm{aA}}$ & $26.40 \pm 3.05^{\mathrm{aA}}$ & $45.80 \pm 11.80^{\mathrm{aA}}$ & $30.37 \pm 0.43^{\mathrm{aA}}$ \\
$\mathrm{AC}$ & $53.33 \pm 11.57^{\mathrm{aA}}$ & $43.46 \pm 1.91^{\mathrm{aA}}$ & $116.33 \pm 12.87^{\mathrm{bB}}$ & $75.88 \pm 6.32^{\mathrm{bB}}$ \\
30 & $68.33 \pm 17.92^{\mathrm{aA}}$ & $45.75 \pm 5.62^{\mathrm{aA}}$ & $125.33 \pm 11.16^{\mathrm{bB}}$ & $62.55 \pm 7.16^{\mathrm{bA}}$ \\
300 & $109.85 \pm 23.54^{\mathrm{bA}}$ & $53.94 \pm 6.39^{\mathrm{bA}}$ & $159.00 \pm 13.83^{\mathrm{bB}}$ & $67.06 \pm 9.41^{\mathrm{bA}}$ \\
\hline & $\mathrm{Na}^{+}(\mathrm{mmol})$ & $\mathrm{K}^{+}(\mathrm{mmol})$ & $\mathrm{Na}^{+}(\mathrm{mmol})$ & $\mathrm{K}^{+}(\mathrm{mmol})$ \\
\cline { 2 - 5 } $\mathrm{BC}$ & $175.00 \pm 8.21^{\mathrm{aA}}$ & $3.52 \pm 0.45^{\mathrm{aA}}$ & $226.20 \pm 13.46^{\mathrm{bB}}$ & $3.80 \pm 0.70^{\mathrm{aA}}$ \\
$\mathrm{AC}$ & $165.25 \pm 11.15^{\mathrm{aA}}$ & $3.08 \pm 0.66^{\mathrm{aA}}$ & $220.80 \pm 4.57^{\mathrm{bB}}$ & $2.12 \pm 0.23^{\mathrm{aA}}$ \\
30 & $161.60 \pm 12.49^{\mathrm{aA}}$ & $4.02 \pm 0.65^{\mathrm{aA}}$ & $197.80 \pm 17.71^{\mathrm{bB}}$ & $2.58 \pm 0.50^{\mathrm{aA}}$ \\
300 & $191.75 \pm 9.89^{\mathrm{aA}}$ & $3.48 \pm 0.81^{\mathrm{aA}}$ & $221.60 \pm 5.75^{\mathrm{bA}}$ & $2.04 \pm 0.40^{\mathrm{aA}}$ \\
\hline
\end{tabular}

compounds, but the concentration of the substances varies according to the development stage of the leaves. For the EO of the same species growing in São Paulo state (Brazil), literature describes $\alpha$-bisabolol as major constituent (Romoff et al., 2010).

The major compounds of EO of $N$. megapotamica can play an important role in the observed pharmacological effect. Both $\alpha$ - and $\beta$-pinene have been reported as sedatives (Mercier et al., 2009) and analgesics (Erazo et al., 2006). Kasanen et al. (1998) also reported that all pinenes induced sedation followed by signs of anesthesia in mice. Moreover, $\alpha$-pinene is reported as positive

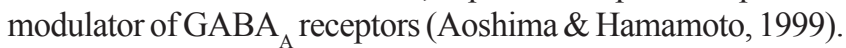
These receptors are recognized as important targets for modulation by sedative, anxiolytic and general anesthetic agents (Franks \& Lieb, 1994). Del-Vechio-Vieira et al. (2009) described the analgesic activity of EO from leaves of Ageratum fastigiatum in mice, whose main component was germacrene D. Studies regarding this activity related to bicyclogermacrene were not found in literature. To the best of our knowledge this is the first study that describes the anesthetic activity of this EO.

Results of the anesthetic activity have shown that the concentration required of both EOs of $N$. megapotamica to induce mild sedation in fat snook adapted to both salinities was $30 \mu \mathrm{L} \mathrm{L}^{-1}$. At concentrations of $150 \mu \mathrm{L} \mathrm{L}^{-1}$ or higher, the induction of deep anesthesia (stage 4) was achieved in 5.6-8.0 min. Although ethanol has presented anesthetic effect at the highest concentration used to dilute the EO, this effect was weaker than the effect observed for the oil and was transient. The recovery time of anesthesia induced for this concentration varied between 5.5-11.0 min. According to Marking \& Meyer (1985) an ideal fish anesthetic should induce anesthesia in less than three min, and the recovery should occur within five min. Studies with EOs of different plant species have shown variations in efficacy and safety, depending on the chemical composition and the fish species tested. Menthol, the main component of EO of plants from genus Mentha, can induce 
Table 4. Tissue water content (\%) in fat snook Centropomus parallelus, under control conditions (BC: basal control; AC: aquarium control) or submitted to the essential oil from old leaves of Nectandra megapotamica (30 and $\left.300 \mu \mathrm{L} \mathrm{L}^{-1}\right)$. Data presented as means $\pm \operatorname{SEM}(n=6)$. No significant difference between groups was observed $(\mathrm{P}>0.05)$.

\begin{tabular}{cccccc}
\hline \multirow{2}{*}{ Groups } & \multicolumn{3}{c}{ tissue water content $\%$} \\
& \multicolumn{2}{c}{ Freshwater } & & \multicolumn{2}{c}{ Seawater } \\
\cline { 2 - 3 } \cline { 5 - 7 } BC & $73.30 \pm 0.82$ & $79.94 \pm 0.53$ & & $70.40 \pm 2.86$ & $76.55 \pm 0.75$ \\
AC & $72.25 \pm 0.63$ & $79.48 \pm 0.31$ & & $72.33 \pm 0.96$ & $77.65 \pm 0.73$ \\
30 & $74.05 \pm 1.60$ & $80.77 \pm 0.42$ & & $70.70 \pm 1.94$ & $78.60 \pm 0.61$ \\
300 & $73.00 \pm 1.18$ & $80.17 \pm 0.84$ & & $68.50 \pm 0.80$ & $76.36 \pm 0.60$ \\
\hline
\end{tabular}

deep anesthesia in Colossoma macropomum at $100 \mathrm{mg} \mathrm{L}^{-1}$ in $4.39 \mathrm{~min}$, whereas recovery occurred in $5.04 \mathrm{~min}$ (Façanha and Gomes, 2005) and for the same concentration in Piaractus mesopotamicus induction and recovery time were less than two min (Gonçalves et al., 2008). The EO of Lippia alba was effective to induce stage 4 in silver catfish (Rhamdia quelen) at $300 \mathrm{mg} \mathrm{L}^{-1}$ in $3.8 \mathrm{~min}$ and recovery in $6.4 \mathrm{~min}$ (Cunha et al., 2010a). The effect of eugenol (major component of clove oil), varies according to the species of fish, but $30-50 \mathrm{mg} \mathrm{L}^{-1}$ induced deep anesthesia within 2-8 min in red pacu, Piaractus brachypomus (Sladky et al., 2001), silver catfish, Rhamdia quelen (Cunha et al., 2010b), and goldfish, Carassius auratus (Abdolazizi et al., 2011). The recovery time ranged from 1-10 min. In general, the recovery time of the EO-O was higher than $\mathrm{EO}-\mathrm{Y}$, and this may be due to the difference in the concentrations of the components of EOs.

The efficacy of anesthetic agents can be affected by biological (species, age, size, and sex) and environmental (salinity, $\mathrm{pH}$, oxygen level, and water temperature) factors (Ross \& Ross, 2008). In this study, we compared the anesthetic activity of EO of $N$. megapotamica at different salinities through the times of induction and recovery of anesthesia and, in general terms, there was a shorter induction and recovery times in $\mathrm{FW}$ - adapted fat snook. Ghazilou et al. (2010) observed that Caspian salmon [Salmo trutta caspius (= Salmo caspius)] exposed to clove oil at different salinity levels showed an increase in the induction time with increasing salinity. According to Ross \& Ross (2008), due to the buffering capacity of SW and its ionic constituents, the effects of some drugs may be modified in SW.

Euryhaline fish maintain plasma glucose and lactate levels constant within their optimum salinity range, and alterations are observed when these fish are exposed to extreme salinities (Arjona et al., 2007; Herrera et al., 2009). No significant changes were observed in these parameters in fat snooks, indicating that the acclimation to FW and SW did not require higher energy demand. Some anesthetics can inhibit stress by acting on the hypothalamo-pituitary-interrenal (HPI) axis reducing or blocking its activity (Oslen et al., 1995). Failure to suppress the activation of the HPI axis during stress results in rapid release of catecholamines and consequent increase in circulating levels of glucose and lactate (Barton, 2002). Results observed in the present study showed that the EO-O of $N$. megapotamica did
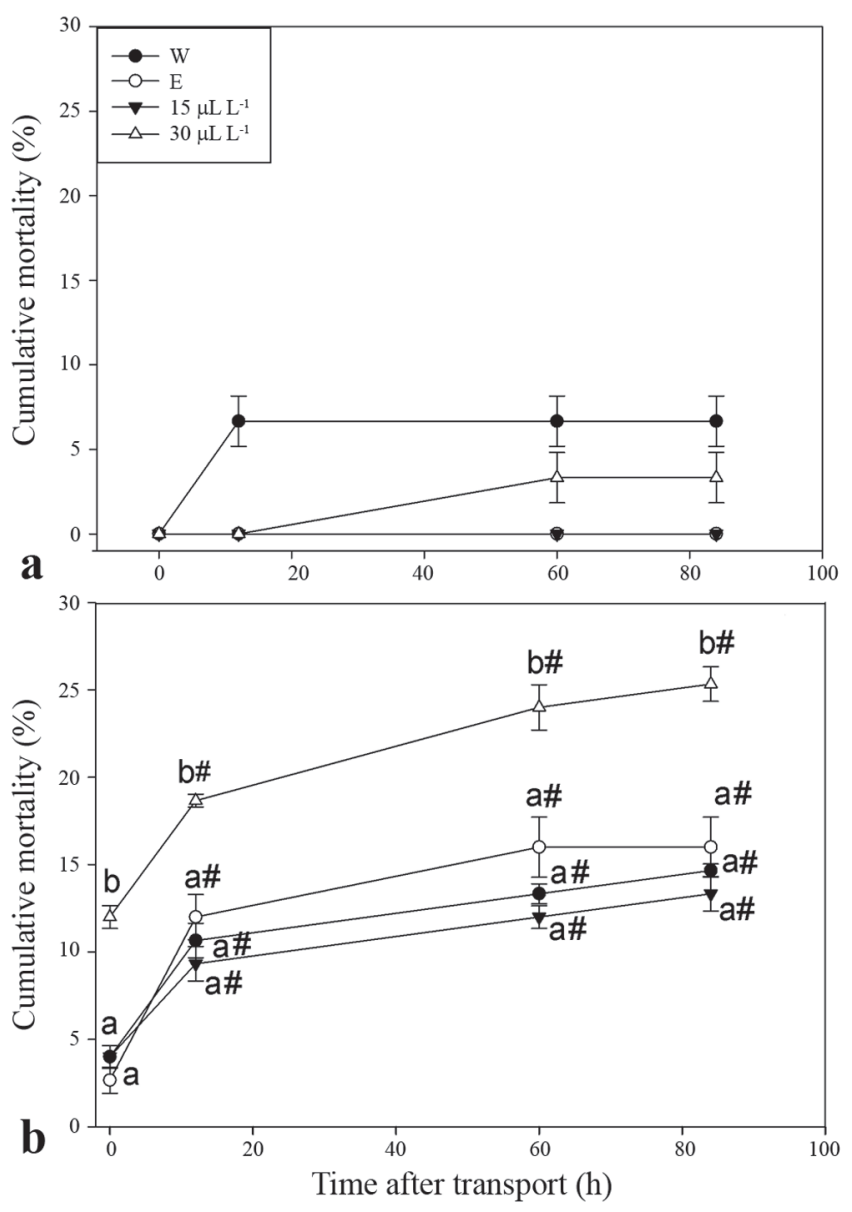

Fig. 1. Mortality after transport of fat snook Centropomus parallelus in plastic bags with essential oil from old leaves of Nectandra megapotamica $\left(15\right.$ or $\left.30 \mu \mathrm{L} \mathrm{L}^{-1}\right)$ or ethanol (E) added to the water. W: control with only water. Data presented as means $\pm \operatorname{SEM}(n=3)$. a, freshwater - no significant difference between groups or times was observed and the treatments $\mathrm{E}$ and $15 \mu \mathrm{L} \mathrm{L}^{-1}$ are superimposed on the first line $; \mathbf{b}$, seawater values with different superscripts are significantly different $(\mathrm{P}$ $<0.05)$. \# Significant difference from arrival $(0 \mathrm{~h})$.

not change plasma glucose levels in SW-adapted fat snooks. However, in fish maintained in FW the exposure to the higher concentration tested of this EO apparently induced stress because plasma glucose and lactate levels were significantly higher than in fish from other treatments. Elevated levels of glucose were also observed after the induction of anesthesia with eugenol in common carp (Velisek et al., 2005), and rock bream, Oplegnathus fasciatus (Park et al., 2009). Rise of plasma lactate concentration was also reported with the use of eugenol in Nile tilapia, Oreochromis niloticus (Deriggi et al., 2006).

According to Lee et al., 2009, among the secondary responses to stress, osmoregulatory disturbances may be observed and evidenced by changes in water content of tissues and plasma ions. Muscle and gill water content can be used as a physiological index to evaluate the balance of water content in 
fish. Our results showed no significant change in water content of fat snook muscle and gills or $\mathrm{Na}^{+}$and $\mathrm{K}^{+}$plasma levels between anesthetized fish and controls in the same salinity. Plasma ion levels of fat snook were within the expected range for tropical fish (Becker et al., 2011). SW-adapted fish showed a higher $\mathrm{Na}^{+}$ plasma levels than FW-adapted ones, and this was expected because SW acclimation increased osmolality in Mozambique tilapia (Oreochromis mossambicus) (Fiess et al., 2007) and plasma level of $\mathrm{Na}^{+}$and $\mathrm{Cl}^{-}$in European flounder (Platichthys flesus) (Lundgreen et al., 2008), Micropogonias furnieri and Genidens barbus (Becker et al., 2011) compared to FW-adapted specimens.

Control of water quality and fish sedation during transport can be useful tools to minimize stress (Ross \& Ross, 2008). In the present study, water quality at the end of transport was within acceptable values for snooks (Alvarez-Lajonchere \& Tsuzuki, 2008). Unionized ammonia $\left(\mathrm{NH}_{3}\right)$ levels at the end of transport were 0.0085 and $0.016 \mathrm{mg} \mathrm{L}^{-1}$ for FW and SW, respectively, therefore much lower than toxic levels for fish (Randall \& Tsui, 2002; Miron et al., 2008). However, EO-O did not reduce ammonia excretion, and consequently did not prevent deterioration in water quality post-transport. In addition, mortality was not lower with the use of EO-O, on the contrary, fish transported with the higher concentration of EO in SW had significantly higher mortality than the other groups. Several studies have shown that sedation can decrease post-transport mortality (Inoue et al., 2005; Iversen et al., 2009; Pramod et al., 2010). However, in this study an increase of mortality after transport was detected at $30 \mu \mathrm{1} / \mathrm{L}$ EO-O. This could be related to the concentration and duration of exposure during transport in this study. In conclusion, the EO of $N$. megapatomica is effective at inducing mild sedation and deep anesthesia in $C$. parallelus, however, it does not prevent the stress caused by anesthesia and transport according to parameters analyzed. Further studies aiming to isolate the substances with anesthetic potential and activity tests with different fish species, as well as other stress parameters (e.g., cortisol) may better elucidate the anesthetic activity of this essential oil.

\section{Acknowledgments}

This study was supported by CNPq (Conselho Nacional de Desenvolvimento Científico e Tecnológico, process 470964/ 2009-0 and process 559090/2009-9 and - FAPERGS- PRONEX process 10/0016-8). B. Baldisserotto, L. C. Gomes and C. A. Mallmann received a CNPq, L. P. Amaral a CAPES (Coordenação de Aperfeiçoamento de Pessoal de Nível Superior, Brazil) PhD fellowship. Additionally, Q. Garlet recieved a FIT/UFSM (Fundo de Incentivo Tecnológico da UFSM), B. Schindler and T. M. Oliveira a FIPE/UFSM (Fundo de Incentivo à Pesquisa da UFSM) fellowship. The authors thank Prof. Solon Jonas Longhi for locating and identifying the plant species.

\section{Literature Cited}

Abdolazizi, S., E. Ghaderi, N. Naghdi \& B. B. Kamangar. 2011. Effects of clove oil as an anesthetic on some hematological parameters of Carassius auratus. Journal of Aquaculture Research \& Development, 2: 1-3

Adams, R. P. 2001. Identification of essential oil components by gas chromatography/ quadrupole mass spectroscopy, Carol Stream, Ill., Allured Pub. Corporation.

Alvarez-Lajonchere, L. \& M. Y. Tsuzuki. 2008. A review of methods for Centropomus spp. (snooks) aquaculture and recommendations for the establishment of their culture in Latin America. Aquaculture Research, 39: 684-700.

Alves, E. O., J. H. Mota, T. S. Soares, M. C. Vieira \& C. B. da Silva. 2008. Levantamento etnobotânico e caracterização de plantas medicinais em fragmentos florestais de Dourados-MS. Ciência Agrotécnica, 32: 651-658.

Alves, F. M. \& A. L. B. Sartori. 2009. Nectandra Rol. ex Rottb. (Lauraceae) no Mato Grosso do Sul, Brasil. Acta Botanica Brasilica, 23: 118-129.

American Public Health Association., American Water Works Association., Water Pollution Control Federation. \& Water Environment Federation. 1998. Standard methods for the examination of water and wastewater, New York, American Public Health Association.

Aoshima, H. \& K. Hamamoto. 1999. Potentiation of GABA(A) receptors expressed in Xenopus oocytes by perfume and phytoncid. Bioscience Biotechnology and Biochemistry, 63: 743-748.

Apel, M. A., M. E. L. Lima, A. Souza, I. Cordeiro, M. C. M. Young, M. E. G. Sobral, I. B. Suffredini \& P. R. H. Moreno. 2006. Screening of the biological activity from essential oils of native species from Atlantic rain forest (São Paulo - Brazil). Pharmacologyonline, 3: 376-383.

Arjona, F. J., L. Vargas-Chacoff, I. Ruiz-Jarabo, M. P. M. del Rio \& J. M. Mancera. 2007. Osmoregulatory response of Senegalese sole (Solea senegalensis) to changes in environmental salinity. Comparative Biochemistry and Physiology A-Molecular \& Integrative Physiology, 148: 413-421.

Barton, B. A. 2002. Stress in fishes: A diversity of responses with particular reference to changes in circulating corticosteroids. Integrative and Comparative Biology, 42: 517-525.

Becker, A. G., J. F. Gonçalves, J. A. Toledo, M. D. M. Burns, L. O. Garcia, J. Vieira \& B. Baldisserotto. 2011. Plasma ion levels of freshwater and marine/estuarine teleosts from Southern Brazil. Neotropical Ichthyology, 9: 859-900.

Council of Europe, European Directorate for the Quality of Medicines \& Healthcare \& European Pharmacopoeia Commission. 2007. European Pharmacopoeia, Strasbourg, Council of Europe : European Directorate for the Quality of Medicines and Healthcare.

Cunha, M. A., F. M. C. de Barros, L. O. Garcia, A. P. L. Veeck, B. M. Heinzmann, V. L. Loro, T. Emanuelli \& B. Baldisserotto. 2010a. Essential oil of Lippia alba: A new anesthetic for silver catfish, Rhamdia quelen. Aquaculture, 306: 403-406.

Cunha, M. A., C. C. Zeppenfeld, L. O. Garcia, V. L. Loro, M. B. Fonseca, T. Emanuelli, A. P. L. Veeck, C. E. Copatti \& B. Baldisserotto. 2010b. Anesthesia of silver catfish with eugenol: Time of induction, cortisol response and sensory analysis of fillet. Ciência Rural, 40: 2107-2114.

da Silva, A. A., M. L. A. E. Silva, J. C. T. Carvalho \& J. K. Bastos. 2004. Evaluation of analgesic and anti-inflammatory activities of Nectandra megapotamica (Lauraceae) in mice and rats. Journal of Pharmacy and Pharmacology, 56: 1179-1184.

Del-Vechio-Vieira, G., O. V. de Sousa, M. A. Miranda, L. SennaValle \& M. A. C. Kaplan. 2009. Analgesic and anti-inflammatory 
properties of essential oil from Ageratum fastigiatum. Brazilian Archives of Biology and Technology, 52: 1115-1121.

Deriggi, G. F., L. A. K. A. Inoue \& G. Moraes. 2006. Stress responses to handling in Nile tilapia (Oreochromis niloticus Linnaeus): assessment of eugenol as an alternative anesthetic. Acta Scientiarum. Biological Sciences, 28: 269-274.

Erazo, S., C. Delporte, R. Negrete, R. Garcia, M. Zaldivar, G. Iturra, E. Caballero, J. L. Lopez \& N. Backhouse. 2006. Constituents and biological activities of Schinus polygamus. Journal of Ethnopharmacology, 107: 395-400.

Façanha, M. F. \& L. C. Gomes. 2005. A eficácia do mentol como anestésico para tambaqui (Colossoma macropomum, Characiformes: Characidae). Acta Amazonica, 35: 71-75.

Fiess, J. C., A. Kunkel-Patterson, L. Mathias, L. G. Riley, P. H. Yancey, T. Hirano \& E. G. Grau. 2007. Effects of environmental salinity and temperature on osmoregulatory ability, organic osmolytes, and plasma hormone profiles in the Mozambique tilapia (Oreochromis mossambicus). Comparative Biochemistry and Physiology-Part A: Molecular \& Integrative Physiology, 146: 252-264.

Franks, N. P. \& W. R. Lieb. 1994. Molecular and cellular mechanisms of general-anesthesia. Nature, 367: 607-614.

Garcez, F. R., W. S. Garcez, L. Hamerski \& C. H. Miguita. 2009. Phenylpropanoids and other bioactive constituents from Nectandra megapotamica. Química Nova, 32: 407-411.

Ghazilou, A., H. S. Hasankandi, F. Chenary, A. Nateghi, N. Haghi \& M. R. Sahraeean. 2010. The anesthetic efficiency of clove oil in caspian salmon, Salmo trutta caspius K., smolts in dosagesalinity-pH linked approach. Journal of the World Aquaculture Society, 41: 655-660.

Gonçalves, A. F. N., E. C. C. Santos, J. B. K. Fernandes \& L. S. Takahashi. 2008. Mentol e eugenol como substitutos da benzocaína na indução anestésica de juvenis de pacu. Acta Scientiarum Animal Sciences, 30: 339-344.

Gonzalez, R. J., C. M. Wood, R. W. Wilson, M. L. Patrick, H. L. Bergman, A. Narahara \& A. L. Val. 1998. Effects of water pH and calcium concentration on ion balance in fish of the Rio Negro, Amazon. Physiological Zoology, 71: 15-22.

Gray, S. M., F. L. Hart, M. E. M. Tremblay, T. J. Lisney \& C. W. Hawryshyn. 2011. The effects of handling time, ambient light, and anaesthetic method, on the standardized measurement of fish colouration. Canadian Journal of Fisheries and Aquatic Sciences, 68: 330-342.

Herrera, M., L. Vargas-Chacoff, I. Hachero, I. Ruiz-Jarabo, A. Rodiles, J. I. Navas \& J. M. Mancera. 2009. Osmoregulatory changes in wedge sole (Dicologoglossa cuneata Moreau, 1881) after acclimation to different environmental salinities. Aquaculture Research, 40: 762-771.

Inoue, L. A. K. A., L. O. B. Afonso, G. K. Iwama \& G. Moraes. 2005. Effects of clove oil on the stress response of matrinxã (Brycon cephalus) subjected to transport. Acta Amazônica. 35: 289-295.

Iversen, M., R. A. Eliassen \& B. Finstad. 2009. Potential benefit of clove oil sedation on animal welfare during salmon smolt, Salmo salar L. transport and transfer to sea. Aquaculture Research, 40: 233-241.

Kasanen, J. P., A. L. Pasanen, P. Pasanen, J. Liesivuori, V. M. Kosma \& Y. Alarie. 1998. Stereospecificity of the sensory irritation receptor for nonreactive chemicals illustrated by pinene enantiomers. Archives of Toxicology, 72: 514-523.

Lee, T. H., C. H. Tang, C. S. Tzeng \& L. Y. Hwang. 2009. Constant muscle water content and renal HSP90 expression reflect osmotic homeostasis in euryhaline teleosts acclimated to different environmental salinities. Zoological Studies, 48: 435-441.

Lundgreen, K., P. Kiilerich, C. K. Tipsmark, S. S. Madsen \& F. B. Jensen. 2008. Physiological response in the European flounder (Platichthys flesus) to variable salinity and oxygen conditions. Journal of Comparative Physiology B-Biochemical Systemic and Environmental Physiology, 178: 909-915.

Marking, L. L. \& F. P. Meyer. 1985. Are better anesthetics needed in fisheries? Fisheries, 10: 2-5.

Mercier, B., J. Prost \& M. Prost. 2009. The essential oil of turpentine and its major volatile fraction (alpha- and betapinenes): a review. International Journal of Occupational Medicine Environmental Health, 22: 331-342.

Miron, D. S., B. Moraes, A. G. Becker, M. Crestani, R. Spanevello, V. L. Loro \& B. Baldisserotto. 2008. Ammonia and $\mathrm{pH}$ effects on some metabolic parameters and gill histology of silver catfish, Rhamdia quelen (Heptapteridae). Aquaculture, 277: 192-196.

NIST, 2002. NIST/EPA/NIH mass spectral library \& search/analysis programs NIST 02 update. J. Wiley \& Sons, Hoboken.

Oslen, Y. A., I. E. Einarsdottir \& K. J. Nilssen. 1995. Metomidate anaesthesia in atlantic salmon, Salmo salar, prevents plasma cortisol increase during stress. Aquaculture, 134: 155-168.

Palic, D., D. M. Herolt, C. B. Andreasen, B. W. Menzel \& J. A. Roth. 2006. Anesthetic efficacy of tricaine methanesulfonate, metomidate and eugenol: effects on plasma cortisol concentration and neutrophil function in fathead minnows (Pimephales promelas Rafinesque, 1820). Aquaculture, 254: 675-685.

Park, M. O., S. Y. Im, D. W. Seol \& I. S. Park. 2009. Efficacy and physiological responses of rock bream, Oplegnathus fasciatus to anesthetization with clove oil. Aquaculture, 287: 427-430.

Penfold, A. R. \& J. L. Willis. 1961. The eucalypts: botany, cultivation, chemistry, and utilization, London, Leonard Hill.

Pramod, P. K., A. Ramachandran, T. P. Sajeevan, S. Thampy \& S. S. Pai. 2010. Comparative efficacy of MS-222 and benzocaine as anaesthetics under simulated transport conditions of a tropical ornamental fish Puntius filamentosus (Valenciennes). Aquaculture Research, 41: 309-314.

Randall, D. J. \& T. K. N. Tsui. 2002. Ammonia toxicity in fish. Marine Pollution Bulletin, 45: 17-23.

Romoff, P., M. J. P. Ferreira, R. Padilha, D. O. Toyama, O. A. Fávero \& J. H. G. Lago. 2010. Chemical composition of volatile oils from leaves of Nectandra megapotamica Spreng. (Lauraceae). Química Nova, 33: 1119-1121.

Ross, L. G. \& B. Ross. 2008. Anaesthetic and sedative techniques for aquatic animals, Ames, Blackwell.

Santos Filho, D. D. \& B. Gilbert. 1975. Alkaloids of Nectandra megapotamica. Phytochemistry, 14: 821-822.

Sladky, K. K., C. R. Swanson, M. K. Stoskopf, M. R. Loomis \& G. A. Lewbart. 2001. Comparative efficacy of tricaine methanesulfonate and clove oil for use as anesthetics in red pacu (Piaractus brachypomus). American Journal of Veterinary Research, 62: 337-342.

Stoskopf, M. 1993. Anaesthesia. Pp. 161-168. In: Brown, L. (Eds.). Aquaculture for Veterinarians: Fish Husbandry and Medicine. London, Pergamon Veterinary Handbook Series.

Velisek, J., Z. Svobodova, V. Piackova, L. Groch \& L. Nepejchalova. 2005. Effects of clove oil anaesthesia on common carp (Cyprinus carpio L.). Veterinarni Medicina, 50: 269-275.

Submitted November 22, 2012

Accepted June 30, 2013 by Adalberto Val Published September 30, 2013 